Acta Paediatr Scand 68: 161-164, 1979

\title{
S-IgA CHOLERA TOXIN AND ROTAVIRUS ANTIBODY IN HUMAN COLOSTRUM
}

\author{
ALBERTO SIMHON,' ${ }^{2}$ ROBERT H. YOLKEN and LEONARDO MATA" \\ From the 'Instituto de Investigaciones en Salud (INISA), Universidad de Costa Rica, \\ the Ministerio de Salad, San Jose, Costa Rica and the Laboratory \\ of Infectious Diseases, National Institute of Allergy and Infectious Diseases, \\ Bethesda, Maryland, USA
}

\begin{abstract}
Simhon, A., Yolken, R. H. and Mata, L. (Instituto de Investigations en Salud ( INISA), University of Costa Rica, San Jose, Costa Rica). S-IgA cholera toxin and rotavirus antibody inhuman colostrum. Acta Paediatr Scand, 68: 161, 1979.-S-1gA antibodies against cholera toxin and rotavirus were assayed in $\mathbf{4 3}$ colostral samples by means of an enzyme-linked immunosorbent assay (ELISA). Ali specimens contained specific S-1gA antibodies against both antigens. Significant antibody titres to the antigens were demonstrated In almost all colostral samples.
\end{abstract}

KEY WORDS: Anti-cholera toxin, anti-rotavirus, colostrum

The aetiology of "non-specific" infantile diarrhoea has been further elucidated by recognition of the pathogenic role of enterotoxigenic Escherichia colt $(5,12)$ and rotavirus (1, 4). The risk of exposure of infants to these agents, particularly in developing countries, has stimulated study of the protective effect of breast-feeding against their infection and associated diarrhoea.

S-IgA antibodies to enterotoxins of Enterobacteriaceae and Vibrio cholerae have been described in human milk by neutralisation assays and the enzyme-linked immunosorbent assay (ELISA) $(7,15)$. Also, colostra of women from Costa Rica, Guatemala and the United States were found to contain considerable amounts of anti-rotavirus antibody (21). This report describes a semi-quantitative assay of anti-cholera toxin S-IgA antibody by ELISA as an alternative to neutralisation techniques. Furthermore, additional evidence is presented to confirm that colostra from Costa Rican women contain significant levels of anti-rotavirus antibody.

MATERIALS AND METHODS Specimens. Colostrum from 43 women aged 16 to 30 years from San Jose, Costa Rica were b id
72 hours post-partum. Mothers were of a medium-to-low socio-economic status ( approximate per capita yearly income, US $\$ 70-150)$. All were at least minimally literate. S-IgA was assayed by the ELISA $(2.17)$ in a modification developed by Yoiken et al. for rotavirus antigen (20), for labile toxin of $E$. calf (19), and for rotavirus antibody assay (21)

ELISA for cholera toxin antibody. $2.5 \mathrm{ng}$ of cholera toxin (Schwarz Mann, Inc.,

Orangeburg. N. Y., USA) were added to each well of polyvinyl microtitre plates (Cooke Engineering Co., Alexandria. Virginia. USA) pre-coated with burro anti-cholera toxin antibody. Six fourfold dilutions of each colostrum sample were added in duplicate wells. A conjugate of rabbit anti-secretory component (SC) (Dakopatts AS, Copenhagen, Denmark) and alkaline phosphatase (Sigma Chemical Co, St. Louis, Missouri, USA) was then added to each well. Addition of p-nitrophenyl phosphate substrate produced a yellow colour; the reaction was stopped with $3 \mathrm{~N} \mathrm{NaOH}$ and the colour was read at $400 \mathrm{~nm}$ in a Beckman DU-2 Spectrophotometer.

ELISA for rotavirus antibody. The procedure described by Yolken et al. (21) allowed reaction of a guinea pig anti-rotavirus serum with a rotavirus-positive stool filtrate; the antigen was obtained by experimental infection of a gnotobiotic calf with human rotavirus. This technique was modified as follows: a $2 \%$ suspension of pooled stools from Costa Rican children, positive for rotavirus by both electron microscopy and ELISA, was added to each well of microtitre 


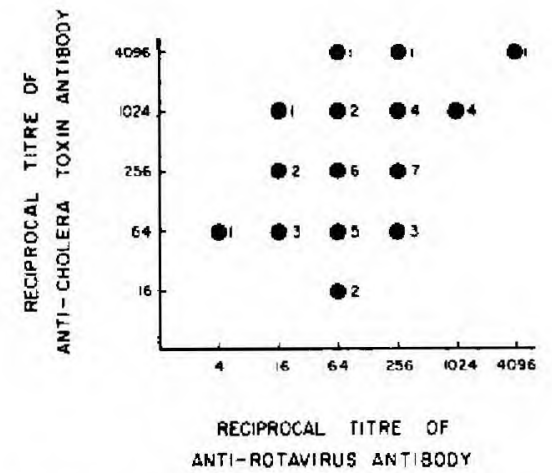

Fig. 1. Scatter diagram of reciprocal anti-cholera toxin and anti-rotavirus antibody titres, 43 colostra from Costa Rican women, 1978. Numeral indicates number of colostra.

to cholera toxin and rotavirus by means of blocking tests (20). In order to remove spurious antibodies to the various reagents in the tests (i. e. immune sera. colostra), those reagents were treated as described by Yolken et al. (22). Addition of colostrum was omitted in negative controls.

ELISA end-point titres. To determine the titre of specific S-IgA, positive/negative (P/N) values were determined for each colostrum by dividing the spectrophotometric absorbance of the diluted sample by that of the negative control. A P/N value of 2.0 or greater was considered confirmatory of the presence of SIgA. Reciprocal antibody titres were defined as the highest dilution with a $\mathrm{P} / \mathrm{N}$ value of 2.0 or greater.

\section{RESULTS}

None of the colostral samples contained either cholera toxin or rotavirus antigen. The anti-SC globulin failed to block otherwise positive reactions for cholera toxin and rotavirus antigen.

All colostral samples were shown to contain S-IgA antibodies to both cholera toxin and rotavirus antigen (Table 1). The geometric mean titres of anti-cholera toxin and antirota-virus antibodies were 264.4 and 114.3, respectively. A scatter diagram of reciprocal titres for each colostrum is presented in Fig. 1. A positive-correlating trend was observed. of specific S-IgA antibodies against cholera toxin. Since there has been no evidence of cholera in Costa Rica in this century, it can be advanced that the labile toxin of E. coli ( or of another Enterobacteriaceae) has been the inmunogen eliciting anti-cholera toxin antibody. The fact strengthens the resemblance or identity of these toxins $(6$, 13). Labile toxin (LT) of E. coli was demonstrated by passive immune hemolysis (3) in $9 \%$ of hospitalized diarrhoeic and $6 \%$ of non-diarrhoeic Costa Rican children over a two-year prospective observation (11).

Thus, a high exposure to LT is observed in Costa Rica which presumably is reflected in high antibody titres. Entero-toxinneutralising activity was demonstrated in a large number of specimens of Guatemalan colostrum and Pakistani mature milk, by Stoliar et al. (15) and Holmgren et al. (7), respectively. Inasmuch neutralisation titres were not determined for the Costa Rican colostrum, no comparison can be made with such findings.

The ELISA geometric mean titre of cholera toxin S-IgA in Pakistani milk was significantly lower than that of Costa Rican colostrum, presumably reflecting differences in concentration between milk and colostrum. The possibility that differences resulted from varying experimental conditions should not

Table 1. S-IgA antibody to cholera toxin and rotavirus

\begin{tabular}{ccc}
\hline $\begin{array}{l}\text { Reciprocal } \\
\text { antibody titre }\end{array}$ & $\begin{array}{l}\text { S-IgA } \\
\text { anti-cholera } \\
\text { toxin }\end{array}$ & $\begin{array}{l}\text { S-IgA } \\
\text { anti- } \\
\text { rotavirus }\end{array}$ \\
\hline 4 & 0 & $1(2)^{n}$ \\
16 & $2(5)^{b}$ & $6(14)$ \\
64 & $12(28)$ & $16(37)$ \\
256 & $15(35)$ & $15(35)$ \\
1024 & $11(26)$ & $4(9)$ \\
409 & $3(7)$ & $1(2)$ \\
Total & 43 & 43 \\
\hline
\end{tabular}

a Highest dilution with a $\mathrm{P} / \mathrm{N}$ value of 2 or greater (determined by dividing the spectrophotometric absorbance of the sample by that of the negative control).

- Number of colostra (percentage). 
E. coli heat-labile enterotoxin was unavailable in our laboratory so commercially purified cholera toxin was utilized in this study; antibody end-point titres may have been defined differently in other studies; also, colostra from women of different socio-economic condition may yield different results. The present findings and those of Yolken et al. (21) reveal significant amounts of anti-rotavirus antibody in the majority of colostral specimens, regardless of geographical location. Furthermore, they showed that rotavirus antibody persisted to detectable levels throughout 24 months of lactation. Studies are under way to measure activity in terms of units of neutralisation per $\mathrm{mg}$ of $\mathrm{S}$ IgA.

The correlation trend between titres of anticholera toxin and anti-rotavirus antibodies suggests a similar exposure or response in individual mothers to both antigens.

In a model system of human rotavirus infection in lambs (14) passive immunity was studied by oral administration of human antirotavirus IgG; clinical manifestations were prevented presumably by neutralisation of either the initial inoculum or virus subsequently released by cells, or both. Nosocomial outbreaks of rotavirus have been controlled by oral administration of colostrum (16). Similarly, exclusively breast-fed Indian neonates and young infants of a Guatemalan Mayan village exhibited a lower incidence of gastrointestinal disorders despite frequent exposure to enteropathogens $(9,10)$.

Regarding anti-cholera factors, protection against experimental cholera diarrhoea was shown to result from the synergistic action of anti-bacterial and anti-toxin antibodies (8) . More research is needed to further asess the relative protective role of anti-bacterial and anti-toxin antibodies. Colostral IgG and IgM antibodies, already demonstrated in colostra from Central American women (18), also may provide added protection against enterotoxi-genic and rotavirus infections. other virulence factors is of public health significance, especially in transitional societies now experimenting a decline in breastfeeding. Moreover, the adequacy of passive immunity against toxigenic bacteria and rotaviruses must be evaluated in mature milk and in the various phases of lactation.

\section{ACKNOWLEDGEMENTS}

This work was supported, in part, by the VicePresidency of Research of the University of Costa Rica, and the National Council for Scientific Research and Technology ( CONICIT), Costa Rica. The technical assistance of Patricia Munoz and Roberto Padilla is acknowledged.

\section{REFERENCES}

1. Bishop, R. F., Davidson, G. P., Holmes, I. H. \& Ruck, B. J.: Virus particles in epithelial cells of duodenal mucosa from children with acute non-bacterial gastroenteritis. Lancet, 11: 1281, 1973. 2. Engvall, E. \& Perlmann, P.: Enzymelinked immuno-sorbent assay (FLISA). Ill. Quantitation of specific antibodies by enzyme-labeled anti-immunoglobulin in antigen-coated tubes. J Immunol. 109: 129. 1972.

3. Evans, D. J. \& Evans, D. G.: Direct serological assay for the heat-labile enterotoxin of Escherichia coli using passive immune hemolysis. Infect Imman, 16: 604, 1977.

4. Flewett, T. H., Bryden, A. S. \& Davies, H. A.: Virus particles in gastroenteritis. Lancet, II: 1497, 1973. 5. Gorbach, S. L., Banwell, J. G., Chatterjee, B. D., Jacobs, B. \& Sack, R. B.: Acute undifferentiated human diarrhea in the tropics. I. Alterations in intestinal microflora. J Clin Invest, 50: 881, 1971. 6. Holmgren, J., Soderlind, 0. \& Wadstrom, T.: Cross-reactivity between heat-labile enterotoxins of Vibrio cholerae and Escherichia call in neutralization tests in rabbit ileum and skin. Acta Path Microbial Scand Sect B. 81: 757, 1973. 7. Holmgren, J. Hanson, L. A.. Carlsson. B., Lindblad, B. S. \& Rahimtoola, J.: Neutralizing antibodies against Escherichia roll and Vibrio cholerae entero-toxins in human milk from a developing country. Scand J Immunol, 5: 867, 1976.

8. Holmgren, J. \& Svennerholm, A.: Mechanisms of disease and immunity in cholera: a review. J Infect Dis, 136 (Suppl. ): S 105, 1977. 
II. Reyes, L., Ramirez, J. A., Evans, D. J. \& Mata,

L.: Escherichia coli enterotoxigenica en ninos hospi-talizados de Costa Rica. Rev Med Hosp Nac Ninos (Costa Rica), in press.

12. Sack, R. B., Gorbach, S. L., Banwell, J. G., Jacobs, B., Chatterjee, B.

D. \& Mitra, R. C.: Enterotoxi-genic Escherichia coil isolated from patients with severe cholera-like disease. J Infect Dis, 123: 378. 1971.

13. Smith, N. W. \& Sack, R. B.:

Immunologic cross-reactions of enterotoxins from Escherichia roll and Vibrio cholerae. J Infect Dis, 127: 164, 1973.

14. Snodgrass, D. R., Madeley, C. R., Wells, P. W. \& Angus, K. W.: Human rotavirus in lambs: infection and passive protection. Infect lmmun, /6:268, 1977. Stoliar, 0. A.. Pelle)/ • R. P.. KanieckeGreen, E., Klaus, M. H. \& Carpenter, C. C. J.: Secretory $\operatorname{IgA}$ against enterotoxins in breast-milk. Lancet, I: 1258. 1976. 16. Totterdal, B. M., Chrystie, I. L. \& Banatvala, J. E.: Rotavirus infection in a maternity unit. Arch Dis Child, 51: 924. milk of Guatemalan Mayan women. Arch La: Am Nutr, 22: 629, 1972.

19. Yolken, R. H., Greenberg, H. B., Merson. M. H., Sack, R. B. \& Kapikian, A. Z.: Enzyme-linked im-munosorbent asssay for detection of Escherichia coil heat-labile enterotoxin. J Clin Microbiol, 6:439, 1977. 20. Yolken, R. H., Kim, H. W., Clem, T., Wyatt, R. G., Kalica, A. R., Chanock, R. M. \& Kapikian. A. Z.: Enzyme-linked immunosorbent assay (ELISA) for detection of human reovirus-like agent of infantile gastroenteritis. Lancet, 1 1:263, 1977.

21. Yolken, R. H., Mata, L., Garcia, B., Urrutia, J. J.. Wyatt, R. G., Chanock, R. M. \& Kapikian, A. Z.: Secretory antibody directed against rotavirus in human milk: measurement by means of an enzyme-linked immunosorbent assay ( ELBA). $J$ Pediatr, in press.

22. Yolken, R. H., Wyatt, R. G. \&

Kapikian, A. Z.: ELISA for rotavirus. Lancet, 11: 819, 1977.

Submitted June 2, 1978

Accepted Aug. 31, 1978 